\title{
Telocytes: ultrastructural, immunohistochemical and electrophysiological characteristics in human myometrium
}

\author{
Sanda M Cretoiu ${ }^{1,2}$, Dragos Cretoiu ${ }^{1,3}$, Adela Marin ${ }^{4}$, Beatrice Mihaela Radu ${ }^{4,5}$ \\ and Laurentiu M Popescu ${ }^{1,6}$ \\ ${ }^{1}$ Division of Cellular and Molecular Medicine, Carol Davila University of Medicine and Pharmacy, Bucharest 050474, \\ Romania, Departments of ${ }^{2}$ Ultrastructural Pathology and ${ }^{3}$ Molecular Medicine, Victor Babes National Institute of \\ Pathology, Bucharest 050096, Romania, ${ }^{4}$ Department of Anatomy, Animal Physiology, and Biophysics, Faculty of \\ Biology, University of Bucharest, Bucharest 050095, Romania, ${ }^{5}$ Department of Neurological Sciences (DSNNMM), \\ University of Verona, Verona 37134, Italy and ${ }^{6}$ Division of Advanced Studies, Victor Babeş National Institute of \\ Pathology, Bucharest 050096, Romania
}

Correspondence should be addressed to L M Popescu at Division of Cellular and Molecular Medicine, Carol Davila University of Medicine and Pharmacy; Email: Imp@jcmm.org

\begin{abstract}
Telocytes (TCs) have been described in various organs and species (www.telocytes.com) as cells with telopodes (Tps) - very long cellular extensions with an alternation of thin segments (podomers) and dilated portions (podoms). We examined TCs using electron microscopy (EM), immunohistochemistry (IHC), immunofluorescence (IF), time-lapse videomicroscopy and whole-cell patch voltage clamp. EM showed a three-dimensional network of dichotomous-branching Tps, a labyrinthine system with homocellular and heterocellular junctions. Tps release extracellular vesicles (mean diameter of $160.6 \pm 6.9 \mathrm{~nm}$ in non-pregnant myometrium and $171.6 \pm 4.6 \mathrm{~nm}$ in pregnant myometrium), sending macromolecular signals to neighbouring cells. Comparative measurements (non-pregnant and pregnant myometrium) of podomer thickness revealed values of $81.94 \pm 1.77$ vs $75.53 \pm 1.81 \mathrm{~nm}$, while the podoms' diameters were $268.6 \pm 8.27$ vs $316.38 \pm 17.56 \mathrm{~nm}$. IHC as well as IF revealed double c-kit and CD34 positive results. Time-lapse videomicroscopy of cell culture showed dynamic interactions between Tps and myocytes. In non-pregnant myometrium, patch-clamp recordings of TCs revealed a hyperpolarisation-activated chloride inward current with calcium dependence and the absence of L-type calcium channels. TCs seem to have no excitable properties similar to the surrounding smooth muscle cells (SMCs). In conclusion, this study shows the presence of TCs as a distinct cell type in human non-pregnant and pregnant myometrium and describes morphometric differences between the two physiological states. In addition, we provide a preliminary in vitro electrophysiological evaluation of the non-pregnant state, suggesting that TCs could influence timing of the contractile activity of SMCs.

Reproduction (2013) 145 357-370
\end{abstract}

\section{Introduction}

A lot of information has been gathered on myometrial contractility but the ability of clinicians to pharmacologically manipulate uterine contraction, especially in premature birth, remains limited. Many factors are involved in the regulation of contractility, e.g. mechanical stretch (growing foetus), changes in intercellular signalling (endocrine/paracrine signalling) or the presence of inflammatory cells during spontaneous normal labour (Thomson et al. 1999, Osman et al. 2003, Shynlova et al. 2009, 2010, Hamilton et al. 2012).

The myometrium consists of two important cell populations: smooth muscle cells (SMCs) and interstitial cells. Recently, telocytes (TCs) a novel type of interstitial cell were described (Popescu \& Faussone-
Pellegrini 2010, Faussone-Pellegrini \& Popescu 2011, Gherghiceanu \& Popescu 2012, Popescu \& Nicolescu 2013). TCs are present in almost every major organ in the body, e.g. heart (Faussone-Pellegrini \& Bani 2010, Gherghiceanu \& Popescu 2010, 2012, Gherghiceanu et al. 2010, Kostin 2010, Mandache et al. 2010, Suciu et al. 2010a, Cismasiu et al. 2011, Manole et al. 2011, Rusu et al. 2012c), trachea (Zheng et al. 2011, Rusu et al. 2012a), lungs (Popescu et al. 2011a), blood vessels (Cantarero et al. 2011, Rusu et al. 2011), pancreas (Nicolescu \& Popescu 2012), parotid gland (El-Bassouny 2012, Nicolescu et al. 2012), placenta (Suciu et al. 2010b), urinary tract (Gevaert et al. 2011, Koh et al. 2012), oesophagus (Rusu et al. 2012d), small intestine (Cantarero Carmona et al. 2011, Cretoiu et al. 2012b, 


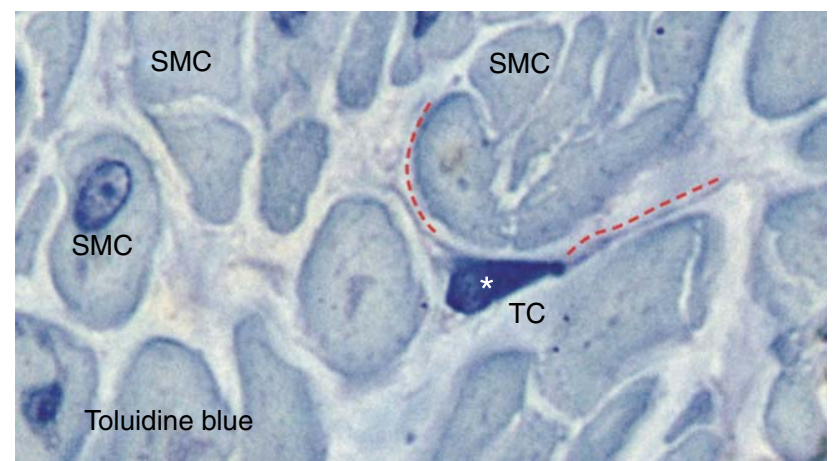

Figure 1 Human pregnant myometrium. Semi-thin sections $(\sim 1 \mu \mathrm{m}$ thick) of Epon-embedded samples, stained with toluidine blue. Typical TCs (red dashed lines) are seen embracing the cross-sectioned SMC. Note the triangular morphology of the TC body $\left({ }^{*}\right)$. Original magnification $100 \times$, oil immersion.

2012c) and endometrium (Hatta et al. 2012). TCs were also identified in: pleura (Hinescu et al. 2011), epicardium (Popescu et al. 2010), skeletal muscle (Bojin et al. 2011, Popescu et al. 2011b, Suciu et al. 2012), skin (Ceafalan et al. 2012, Rusu et al. 2012b) and neuromuscular spindles (Díaz-Flores et al. 2013).

Lately, other research teams adopted the TC notion (e.g. Zhou et al. 2010, Laflamme \& Murry 2011, Liehn et al. 2011, Xiao et al. 2011, Zhou \& Pu 2011, Barile \& Lionetti 2012, Gevaert et al. 2012, Qi et al. 2012, Rosenbaum et al. 2012, Zheng et al. 2012c). The possible role of TCs in pathology was considered (Mandache et al. 2010, Ardeleanu \& Bussolati 2011, Cozzi et al. 2011, Zheng et al. 2012b, Padhi et al. 2013).

The immunohistochemical profile of TCs may differ between organs or even in the same location; however, c-kit is still considered the most specific marker (Popescu \& Faussone-Pellegrini 2010, Cretoiu et al. 2011, 2012a). In scientific literature there is a controversy regarding the presence (Ciontea et al. 2005) or the absence of c-kit (Duquette et al. 2005) expression at uterine interstitial cells level explained by a 'switching' phenotype behaviour in similar cell populations. Some considered that TCs could appear as c-kit negative due to the differences in technical procedures, mainly the type of antibodies (Suciu et al. 2010a, 2010b).

In different organs, TCs have been shown to be present in various types of ionic currents. Transient outward potassium currents in TCs were evidenced through small conductance potassium SK3 channels in bladder (Lee et al. 2012), or through calcium-activated potassium channels in stomach (Kim et al. 2009). On the other hand, transient inward currents are through transient receptor potential (TRP) channels, TRPM7 in gastrointestinal tract (Kim et al. 2011), TRPC3, 6 and 7 in portal vein (Harhun et al. 2006) hyperpolarisation-activated cyclic nucleotide-gated (HCN) channels in gastric antrum (Si et al. 2012), inwardly rectifying chloride channels and calcium-activated chloride channels in the gastrointestinal tract (Zhu et al. 2005, 2011) or in the portal vein (Huang et al. 2010). Rhythmic intracellular calcium discharges originating in TCs are present in the majority of the described structures (Harhun et al. 2006, Zhu et al. 2011), contributing to the pacemaker activity.

In myometrium TCs present only outward potassiumrectifier channels (Duquette et al. 2005, Rosenbaum et al. 2012), but no inward currents have been evidenced so far. There is a lack of regular slow waves of depolarisation in TCs from myometrium (Duquette et al. 2005).

This report provides direct evidence for the existence of TCs in human uterus and makes a morphometric comparison of podomers, podoms and extracellular vesicles (shedding microvesicles (SMVs) and exosomes) in non-pregnant and pregnant myometrium. We outline here TCs' behaviour in cell culture (obtained from non-pregnant myometrium) monitored by time-lapse videomicroscopy. Preliminary patch-clamp data collected from myometrial TCs are also presented.

\section{Results}

\section{In situ TCs identification}

Identification of TCs in human non-pregnant and pregnant myometrium was based on different methods
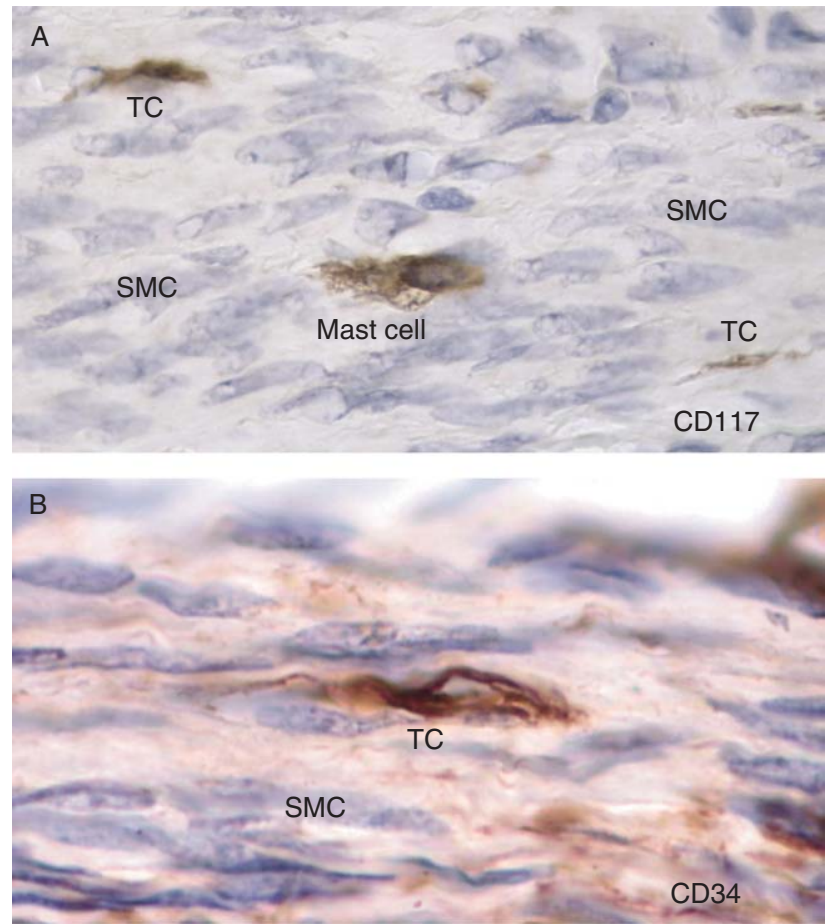

Figure 2 Human pregnant myometrium. Phenotypic profile assessments of paraffin-embedded sections: (A) two spindle-shaped TCs are marked by c-kit staining and can be easily distinguished from a mast cell which can be recognised by its granular content. (B) An elongated TC is detected between myocytes by CD34 staining. Nuclei are counterstained with Mayer's hemalun. Original magnification $100 \times$, oil immersion. 
which complement each other in establishing a positive diagnosis. TCs cannot be seen using a light microscope, as the telopodes (Tps) are below its resolving power, however their presence on semi-thin sections of Eponembedded myometrial fragments stained with toluidine blue can be deduced (Fig. 1). Immunohistochemical characterisation of myometrial TCs disclosed the expression of CD117 and CD34 (Fig. 2).

Electron microscopy (EM) is fundamental in identifying TCs facilitating an accurate diagnosis. We were able to get a better perspective on TCs using two-dimensional reconstruction of successive microscopic fields. The reconstructed collage showed an area much larger and revealed bundles of SMC with dense bodies, thick myosin filaments, caveolae and at least 30 Tps with tortuous trajectories (Fig. 3). Sometimes, EM will only reveal Tps fragments, which may explain why TCs were constantly ignored or overlooked.

Ultrastructural identification of TCs is based on the following features which allow their differentiation from other interstitial-space-resident cells and which can be observed in Fig. 3:

- A small cell body (9-15 $\mu \mathrm{m})$, with a small amount of cytoplasm surrounding the nucleus; scarce cytoplasmic organelles, located mainly in the cell body (e.g. mitochondria 3\%) and endoplasmic reticulum (ER) $1-2 \%$ of cell volume; and cell body shape depends on the number of Tps, but usually is spindly (Fig. 3B) or triangular (Fig. 3A);
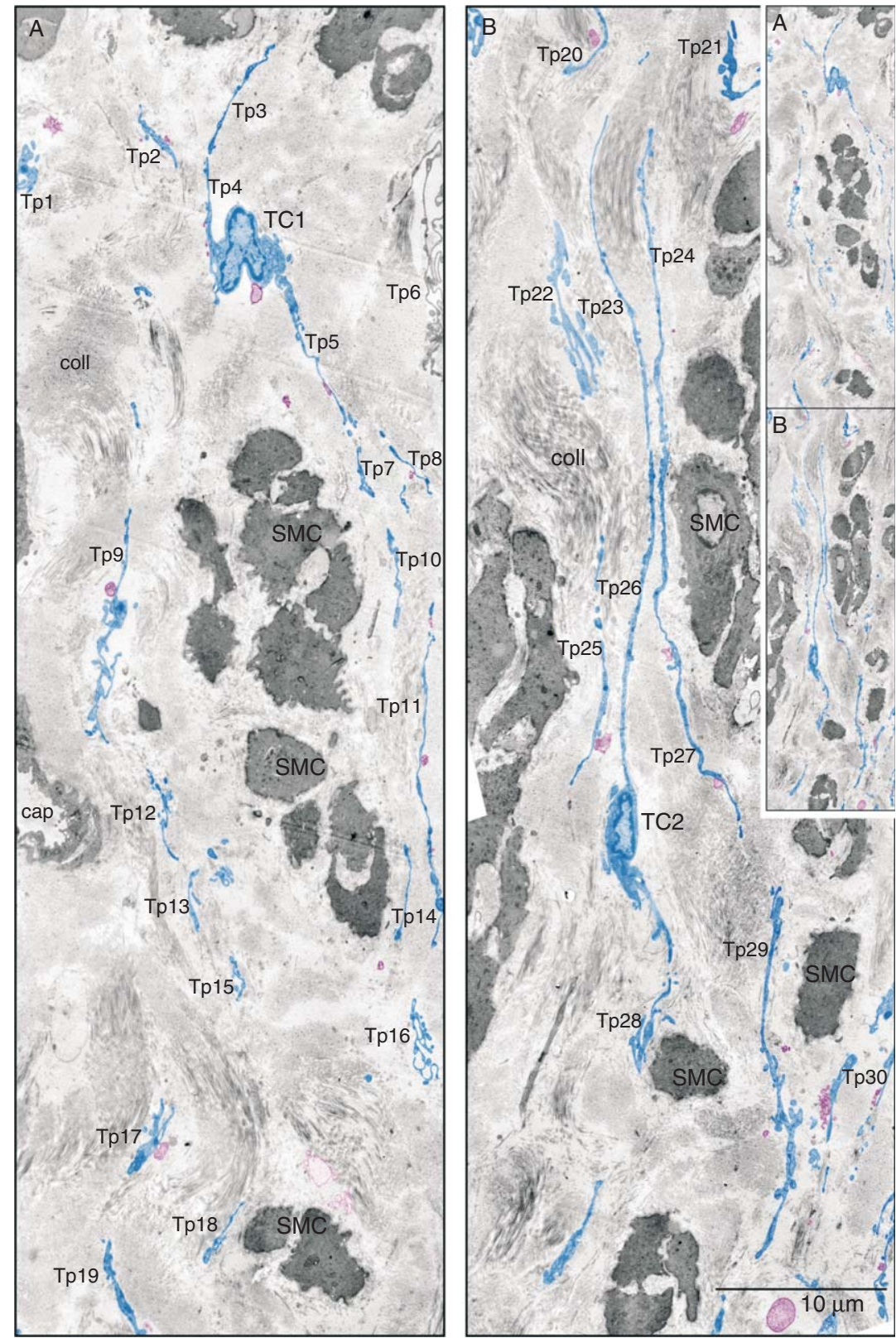

Figure 3 TCs in human non-pregnant myometrium. Two-dimensional sequenced concatenation of six electron micrographs portraying TCs and their Tps digitally coloured in blue. At least $30 \mathrm{Tps}$ can be counted in the two-dimensional reconstruction. The inset demonstrates the continuity of figures (A) and (B). (A) One can observe a triangular TC1 cell body in the interstitial space between smooth muscle cells (SMC). (B) A spindle-shaped TC2 from which are detached very long Tps. In both TCs note the heterochromatin mostly confined to the periphery of the nucleus but also dispersed throughout. Tps of different TCs can be seen across the space between SMC. Tps are highlighted in blue revealing a network disposition. Most times they are disposed in parallel (B) and surround collagen bundles of different orientations. All Tps and have dilated regions - podoms - and thin segments - podomers. Released vesicles (coloured purple) can be seen emerging or in close proximity of Tps. Vesicles can be formed either by TC membrane blebbing (SMVs) or by TC secretion (exosomes). Sometimes, Tps are seen forming a labyrinthine system by threedimensional convolution and overlapping - Tp9, Tp16 and Tp21 - and are communicating through junctions. The inset shows that images (A) and (B) are continuous and represent a two-dimensional concatenation of eight sequenced micrographs. 
- The nucleus is characterised by a moderately dense chromatin (heterochromatin); and

- Tps have specific and defining characters: number: 1-5/cell, usually 1-3; branching in a dichotomous pattern; length: very long $(10-1000 \mu \mathrm{m})$ and thin $(0.1 \pm 0.5 \mu \mathrm{m})$; aspect: 'bead-on-a-string' appearance - podomers alternating with podoms; and intercellular connections consisting of homo- and heterocellular junctions (as suggested by Cretoiu et al. (2012b, 2012c)).

We found that the connective tissue atmosphere between the SMC is dominated by collagen fibril
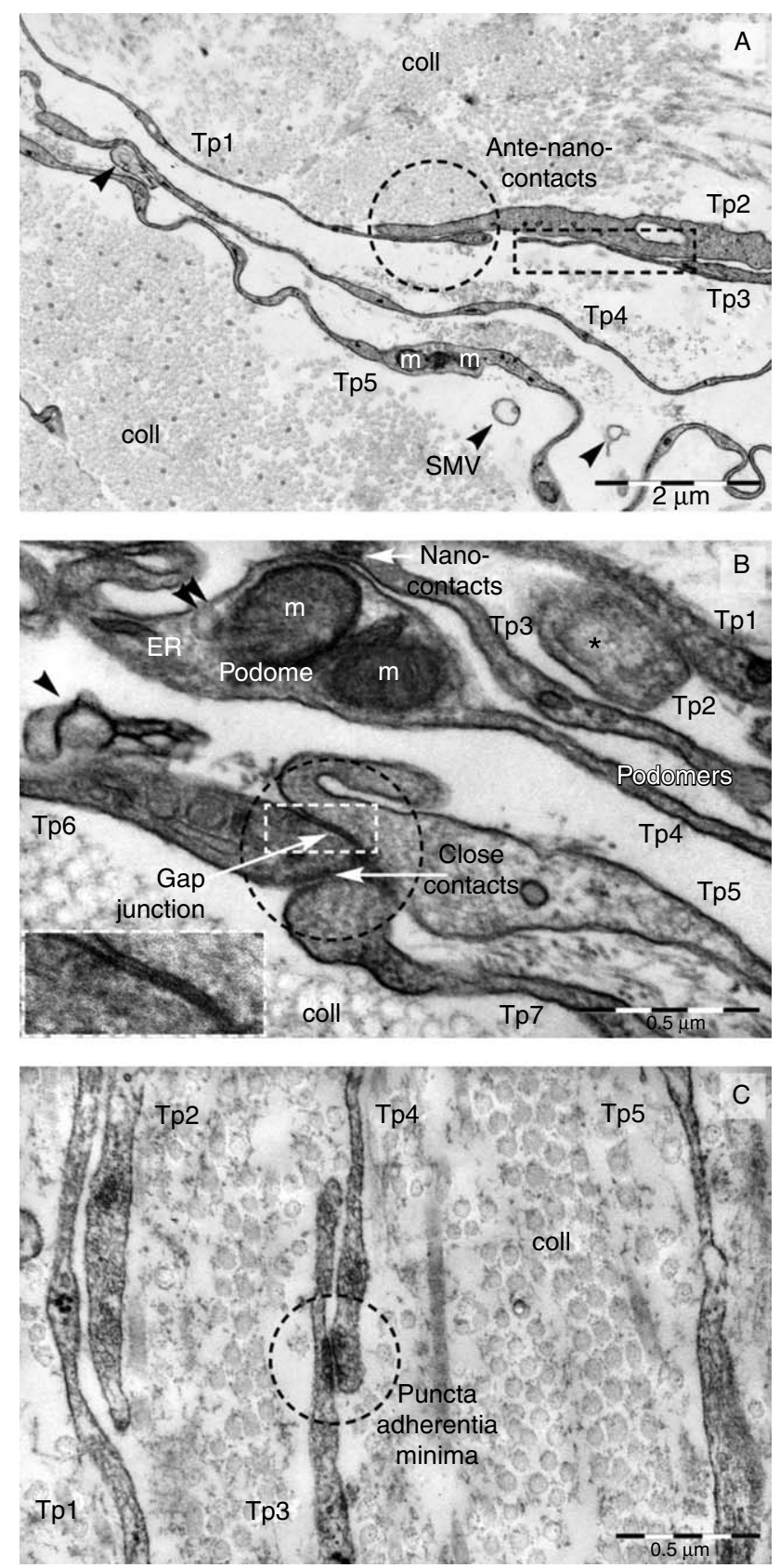

bundles at various section angles (Figs 3 and 4). The collagen fibrils are bordered/organised by several long parallel Tps (Fig. 3A). Tps were arranged one after another and set up homocellular contacts between TCs at distances between 10 and $30 \mathrm{~nm}$, suggesting a molecular interaction between different TCs (Fig. 4). Tps labyrinthine trajectory requires suitable section planes, in order to cover a reasonably long Tp (Fig. 3).

TCs are coupled through:

- close contacts and nanocontacts (Fig. 4A and B);

- 'classical' cell-cell junctions such as gap junctions (Fig. 4B); and

- atypical homocellular junctions such as the tiny puncta adhaerentia minima (Fig. 4C) and processus adhaerentes (Fig. 4B).

Identification of TCs in the human pregnant and non-pregnant myometrium provided ultrastructural data which allowed comparison of the two physiological states. Podomers' gauge measurements showed different values between non-pregnant and pregnant states of the human uterus, $81.94 \pm 1.77$ vs $75.53 \pm 1.81 \mathrm{~nm}$ (Fig. 5 and Table 1$)(P<0.05$ ANOVA single factor) being under the resolving power of light microscopy, making the EM an essential examination for the study of TCs.

Exosomes (60-100 nm vesicles) and clusters of SMVs (diameters: $250-350 \mathrm{~nm}$ up to $1 \mu \mathrm{m}$ ) were frequently released from Tps (Figs 3 and $4 \mathrm{~A}$ and $\mathrm{B}$ ). Evidence of exosomes/SMVs was noted at a slighter lower rate in non-pregnant uterus compared with pregnant myometrium (Fig. 6 and Table 2). In non-pregnant uterus, the diameter of extracellular vesicles measured in the myometrial interstitium varied between 58 and $405 \mathrm{~nm}$,

Figure 4 High-magnification micrographs of ultrathin sections. TC-TC junctions between Tps in human non-pregnant ( $\mathrm{A}$ and $\mathrm{B}$ ) and pregnant myometrium (C). (A) Three overlapping Tps (Tp1, Tp2 and Tp3) are connected by nanocontacts. In the encircled dotted area the two plasma membranes overlap over a length of $1.1 \mu \mathrm{m}$ and are spaced at an average distance of $13 \mathrm{~nm}$. The rectangle dotted area depicts an intermediate phase before the nanocontacts are formed that we called ante-nanocontacts where overlapping membranes (over a distance of $2.1 \mu \mathrm{m})$ are at a mean distance of $30 \mathrm{~nm}$. Note the mitochondria $(\mathrm{m})$ which are frequently seen in the podoms. SMVs (arrowheads) are often captured and suggest a transfer of information between Tp4 and Tp5. (B) Numerous Tps (Tp1-Tp7) in a region of close interrelations. Tp1 came in close contact with a cross-cut $(*) \mathrm{Tp} 2$ at distances between 7 and $12 \mathrm{~nm}$ within a $0.2-\mu \mathrm{m}$ distance. In the middle upper part of the image one can observe a nanocontact between Tp3 and a podom rich in mitochondria $(\mathrm{m})$ caveolae (arrowhead) and ER. Intermembrane distance is $13 \mathrm{~nm}$ and the planar contact is $0.30 \mu \mathrm{m}$ long. The encircled dotted area reveals different junctions between three Tps: a gap junction - intermembrane space $4 \mathrm{~nm}, 0.26$ long, and two close contacts - both of $8 \mathrm{~nm}$ wide, 0.3 and $0.2 \mu \mathrm{m}$ long respectively. The white dotted rectangle shows details of the gap junction: the intercellular space in this region which is crossed by a central densification. (C) Maximum magnification micrographs in human pregnant myometrium expose an electron-dense nanostructure - a puncta adherentia minima junction between the Tp3 and Tp4 ends. Scale bars: (A) $2 \mu \mathrm{m}$, (B) $0.5 \mu \mathrm{m}$ and (C) $0.5 \mu \mathrm{m}$. 


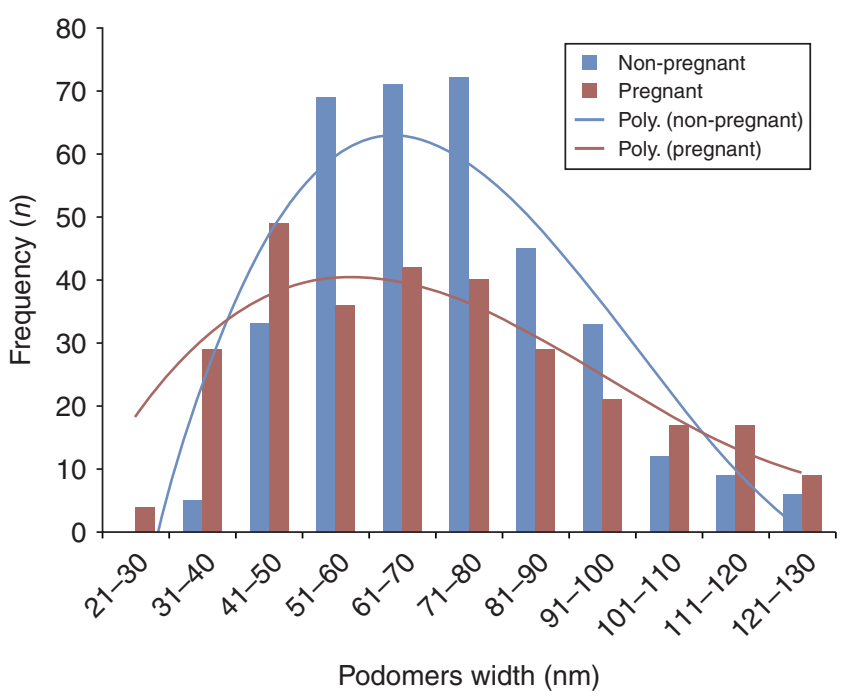

Figure 5 Tps width in human pregnant and non-pregnant myometrium. Third-order polynomial (poly.) trend line that has the best fit to a series of data points showed the distribution of podomers. The Tps widths are more evenly distributed (flatter trend line) in pregnant myometrium compared with non-pregnant myometrium. Most frequent Tps are in the range of 51-60 $\mathrm{nm}$ diameter for pregnant myometrium and 61-70 nm diameter for non-pregnant myometrium.

with most measurements around the median value of $151 \mathrm{~nm}$. Exosomes were found in smaller numbers than SMVs: 26 vs 89. In human pregnant uterus the diameter of secreted vesicles varied between 65 and $362 \mathrm{~nm}$ with most measurements around the median value of $170 \mathrm{~nm}$; exosomes vs SMVs $=20$ vs 168 . The mean diameter of exosomes/SMVs was approximately the same in non-pregnant and pregnant myometrium (Table 2) $(P>0.01 / P>0.5$ two-tailed $t$-test).

\section{In vitro TCs identification}

The distinctiveness of TCs in myometrial primary culture and subsequent passages can be clearly identified by phase contrast microscopy after 4 days in culture before the culture reached confluence. TCs display a particular morphology, defined by very long, moniliform Tps which are not convoluted, and often contact myocytes and other TCs. Frequently, Tps dichotomous branch out forming an interlacing network of long lines. Podoms contain numerous mitochondria demonstrated by Janus green B vital staining, a classic vital stain with high affinity for mitochondria, used to assess viability and localise mitochondria in living cells (Fig. 7). Uterine TCs express the same markers as in situ, at levels detectable by immunofluorescence (IF). Figure 8 depicts the presence of CD117 and CD34 co-localising in the same cell, as punctate staining.

Figure 9 shows that the cell which meets the morphological criteria for TCs extends a very long and thin Tp with characteristic moniliform look. In addition, the $\mathrm{Tp}$ interrelates and communicates with an SMC.
Video 1 (see Supplementary Video 1, see section on supplementary data given at the end of this article) reveals TC as a 'guiding cell' for the co-cultivated SMCs. Fragments of Tps can detach from the cell body leaving behind signalling (macro)molecules ('snow footprints'), probably helping the neighbouring cells to migrate.

\section{In vitro electrophysiology on TCs from non-pregnant uterus}

The electrophysiological properties of TCs were studied using voltage-clamp mode of the patch-clamp technique. Input resistance of TCs had average values of $5.2 \pm 1.0 \mathrm{G} \Omega(n=3)$, and membrane capacitance had average values of $35.7 \pm 12.1 \mathrm{pF} \quad(n=3)$. In Fig. 10A the current-clamp recording clearly shows the absence of slow spontaneous wave in TCs.

However, a series of hyperpolarisation-activated inward currents were recorded from TCs (Fig. 10B) in response to hyperpolarising voltage steps delivered from a holding potential of $-40 \mathrm{mV}$, between -100 and $0 \mathrm{mV}$. The I-V plot (Fig. 10C) was done for hyperpolarisation-activated inward currents shown in Fig. 10B, both at the maximal amplitude of the current (initial potential response) and at the steady-state level (late potential response). The current amplitude has an average value of $-274 \pm 35 \mathrm{pA}(n=3)$ at the voltage step of $-100 \mathrm{mV}$.

Extracellular TEA-Cl and $\mathrm{CsCl}$ were used to block transient outward rectifying potassium channels and $\mathrm{HCN}$ channels respectively. Barium chloride $(20 \mathrm{mM})$ was used to inhibit inward rectifying potassium channels and to follow barium currents through L-type calcium channels, possibly expressed in TCs. No effect was

Table 1 Width of podoms and podomers in human non-pregnant and pregnant myometrium. Podoms' thickness in pregnant myometrium is significantly higher than in non-pregnant myometrium $(P<0.05$ ANOVA single-factor test). Also, podomers' gauge is significantly higher in non-pregnant myometrium compared with pregnant myometrium $(P<0.05$ ANOVA single-factor test).

\begin{tabular}{|c|c|c|c|c|}
\hline & \multicolumn{2}{|c|}{ Podom thickness $(\mathrm{nm})$} & \multicolumn{2}{|c|}{ Podomer gauge $(\mathrm{nm})$} \\
\hline & $\begin{array}{c}\text { Non- } \\
\text { pregnant }\end{array}$ & Pregnant & $\begin{array}{l}\text { Non- } \\
\text { pregnant }\end{array}$ & Pregnant \\
\hline Mean & 268.60 & 316.38 & 81.94 & 75.53 \\
\hline S.E.M. & 8.27 & 17.56 & 1.77 & 1.81 \\
\hline Median & 259.43 & 268.44 & 73.27 & 69.18 \\
\hline S.D. & 83.16 & 176.45 & 35.18 & 31.94 \\
\hline Sample variance & 6915.33 & 31135.07 & 1237.52 & 1020.01 \\
\hline Kurtosis & 0.80 & 6.79 & 7.01 & 1.04 \\
\hline Skewness & 0.74 & 2.24 & 2.26 & 1.02 \\
\hline Range & 421.45 & 1053.80 & 242.55 & 170.05 \\
\hline Minimum & 88.70 & 113.68 & 36.28 & 24.98 \\
\hline Maximum & 510.15 & 1167.47 & 278.83 & 195.02 \\
\hline Sum & 27128.24 & 31954.20 & 32200.60 & 23639.36 \\
\hline Count & 101 & 101 & 393 & 313 \\
\hline $\begin{array}{l}\text { Confidence level } \\
(95 \%)\end{array}$ & 16.42 & 34.83 & 3.49 & 3.55 \\
\hline
\end{tabular}




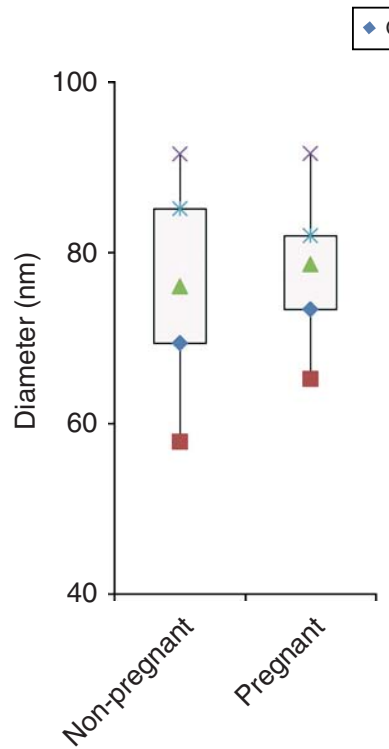

Exosomes

- Q1 $\square$ Minimum $\triangle$ Median $\times$ Maximum $*$ Q3

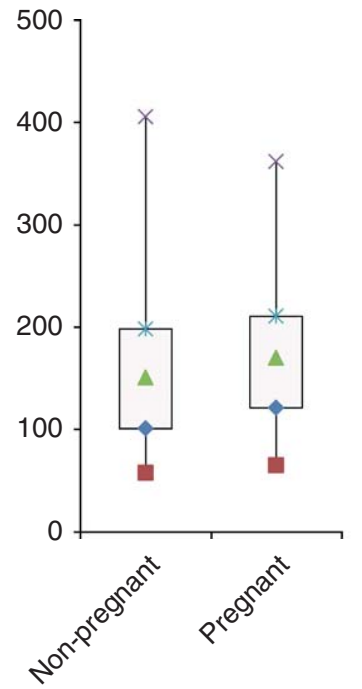

All vesicles

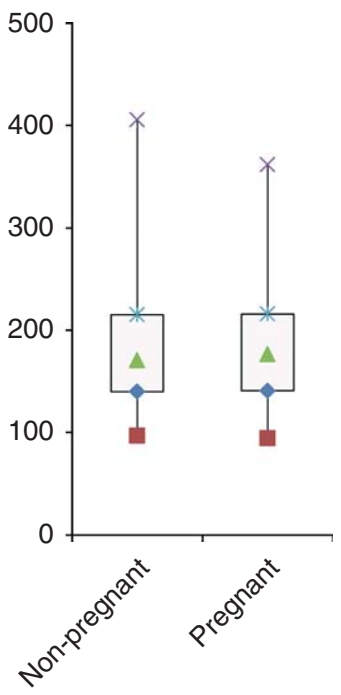

Shedding vesicles
Figure 6 Extracellular vesicles released by Tps into the microenvironment. Boxplots displaying the extremes, the upper and lower quartiles and the median of the maximum difference between the two physiological conditions: pregnant and nonpregnant myometrium (abscissa). The boundary of the box closest to zero indicates the 25th percentile, a green triangle within the box marks the median, and the boundary of the box farthest from zero indicates the 75 th percentile. The measured diameter of membranous extracellular organelles which include SMVs (100-1000 nm) and exosomes (30-90 nm) was expressed in nanometres on the ordinate. obtained upon perfusion for $1 \mathrm{~min}$ of $10 \mu \mathrm{M}$ nifedipine (L-type calcium channel blocker) on TCs from human myometrium, although our data indicate that in rat myometrium preparations TCs are present in similar inward currents partly blocked by nifedipine (data not shown). Therefore, we have concluded that no L-type calcium channels are expressed in TCs from human myometrium.

Mean reversal potential $\left(E_{\text {rev }}\right)$ of these currents was $-6.4 \pm 3.3 \mathrm{mV}(n=3)$, which was very close to the predicted Nernst equilibrium potential of $\mathrm{Cl}^{-}$ $\left(E_{\mathrm{Cl}}=-5.1 \mathrm{mV}\right)$ with an asymmetrical chloride gradient of $\left([\mathrm{Cl}]_{\text {out }} /[\mathrm{Cl}]_{\text {in }}=167 \mathrm{mM} / 136.9 \mathrm{mM}\right)$. Therefore, we hypothesise that inward currents are due to specific chloride ions passing through chloride channels. No testing of chloride channel blockers was done. On the other hand, we tested the calcium dependence of the inward currents and a partial inhibition was observed after pre-treatment of TCs with $50 \mu \mathrm{M} \mathrm{CdCl}_{2}$ (Fig. 10D), so a contribution of the calcium-activated chloride channels to the total hyperpolarisation-activated chloride inward currents might be proposed.

\section{Discussion}

The mechanism by which the myometrial contractility is initiated in a coordinated fashion is still a subject of debate. Uterine myocytes contract via excitationcontraction coupling based on detailed study of cellular mechanisms (Taggart et al. 2012). However, the initiation of electrical signals and the coordination of contractions throughout the organ are, to some extent, unknown.

Our results show the existence of TCs in the human pregnant and non-pregnant myometrium. Previously, myometrial interstitial cells were described by us and other groups (Ciontea et al. 2005, Duquette et al. 2005, Popescu et al. 2007, Allix et al. 2008, Hutchings

Table 2 Comparison between extracellular membranous vesicles found in human uterus: exosomes and SMVs.

\begin{tabular}{|c|c|c|c|c|c|c|}
\hline & \multicolumn{2}{|c|}{ Released vesicles diameters $(\mathrm{nm})$} & \multicolumn{2}{|c|}{ Exosomes diameters $(\mathrm{nm})$} & \multicolumn{2}{|c|}{ Shedding vesicles diameters $(\mathrm{nm})$} \\
\hline & Non-pregnant & Pregnant & Non-pregnant & Pregnant & Non-pregnant & Pregnant \\
\hline Mean & 160.64 & 171.60 & 75.97 & 78.32 & 185.38 & 182.71 \\
\hline S.E.M. & 6.89 & 4.56 & 1.99 & 1.61 & 6.96 & 4.37 \\
\hline Median & 151.03 & 170.30 & 76.07 & 78.63 & 170.58 & 176.59 \\
\hline S.D. & 73.92 & 62.53 & 10.16 & 7.22 & 65.67 & 56.63 \\
\hline Sample variance & 5464.26 & 3910.35 & 103.24 & 52.12 & 4312.63 & 3206.48 \\
\hline Kurtosis & 0.32 & 0.11 & -0.98 & -0.27 & 0.61 & 0.48 \\
\hline Skewness & 0.83 & 0.49 & -0.41 & 0.08 & 1.01 & 0.68 \\
\hline Range & 347.77 & 296.62 & 33.74 & 26.44 & 308.45 & 267.27 \\
\hline Minimum & 57.85 & 65.20 & 57.85 & 65.20 & 97.16 & 94.55 \\
\hline Maximum & 405.61 & 361.82 & 91.59 & 91.64 & 405.61 & 361.82 \\
\hline Sum & 18473.75 & 32261.24 & 1975.32 & 1566.34 & 16498.44 & 30694.90 \\
\hline Count & 115 & 188 & 26 & 20 & 89 & 168 \\
\hline Confidence level (95\%) & 13.66 & 9.00 & 4.10 & 3.38 & 13.83 & 8.63 \\
\hline
\end{tabular}




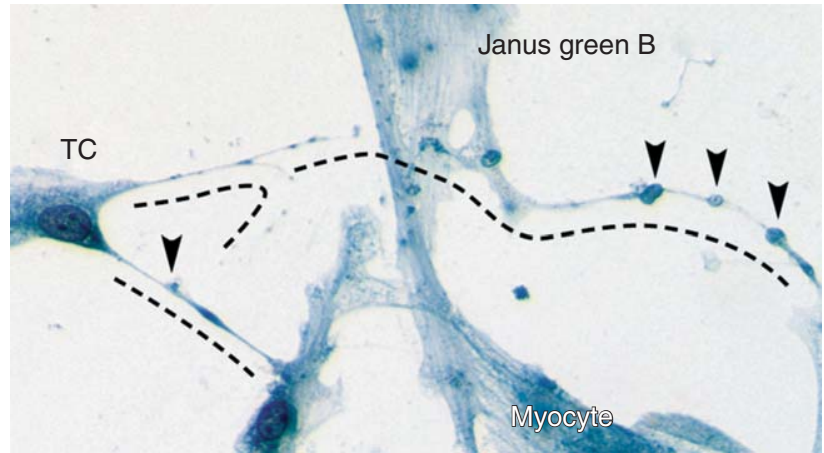

Figure 7 Human pregnant myometrium. TCs in primary semi-confluent cultures (day 4) are vitally stained with Janus green B. The vital staining reveals mitochondria at the level of the cell body and of the podoms (arrowheads). Original magnification $20 \times$. The very long Tps (dashed lines) have a 'bead on a string' appearance - given by the dilated podoms (which accommodate mitochondria) - and pass through or establish contacts with the myocytes.

et al. 2009). The TCs that we now identified in situ and in vitro, by different staining techniques and by EM, correspond presumably to what were previously known as 'myometrial interstitial cells' (Hutchings et al. 2009). The main ultrastructural features of the TCs are the very long Tps with podoms and podomers, a cytoplasm with abundant rough ER, mitochondria, numerous caveolae and well-developed Golgi apparatus. TCs establish several homocellular contacts and are immunoreactive for c-kit and CD34. As previously reported in our studies (Popescu et al. 2005a, Hinescu et al. 2007), TCs are negative for CD68 and other markers associated with immune functions (CD1a, CD62-P), suggesting a clear difference between TCs and macrophages.

The hypothesis that TCs might act as mechanoreceptors has been proposed for rat mesentery (Hinescu et al. 2008). TCs' position in human uterus - at the border of smooth myometrial fibres and also among them - justifies the presumption that they might be capable of detecting and translate stretch information to the nucleus, and activate genes responsible for protein synthesis. The myogenic uterine contractility modulation under hormonal control could involve TCs either by transferring bioactive molecules, either by direct stimulation of myocytes since it was proven that, at least in vitro, TCs express steroid hormone receptors (Cretoiu et al. 2006, 2012a). TCs could also be 'hormonal sensors' in human uterus, since there is evidence of some uterine stromal cells that play a role in endometrial growth and differentiation in a hormone-dependent manner (Bigsby 2002, Cunha et al. 2004) and that endometrial TCs can be isolated in cell culture (Hatta et al. 2012).

The presence of specialised pacemaking cells is now extended to other organs besides the gastrointestinal tract (Takaki et al. 2010). Drawing a parallel between gut TCs (Cretoiu et al. 2012b, 2012c) which are suggested to be cells that might directly or indirectly influence gut motility (Pieri et al. 2008, Faussone-Pellegrini 2009), we can assume that this is also valid for TCs described among uterine myocytes. Tps have in their podoms the so-called calcium uptake/release units (caveolae, mitochondria and ER). The abundance of mitochondria in the podoms correlates with suggested hypotheses on the role of mitochondria as modulators in both pacemaking and contractile activity in the mouse uterus (Gravina et al. 2010). We present here evidence for the existence, in TCs from human non-pregnant myometrium, of an inward hyperpolarising current, with a $\mathrm{Ca}^{2+}$-dependent component. This suggests a role in the excitability of the myometrium. A possible scenario during labour would involve calcium release by SMCs upon contraction, which acts as a stimulus in the extracellular medium of TCs and would partly activate these hyperpolarising chloride inward currents and generate a chloride efflux from TCs. In turn, once they are released from TCs, chloride ions would influence the contractile activity of SMCs.

Several studies have described potassium currents in interstitial cells of Cajal that are involved in shaping the pacemaker potential (Parsons \& Huizinga 2010). It was reported that the total calcium-activated chloride currents prolong the duration of contractions in pregnant myometrium (Young \& Bemis 2009). We may hypothesise that the appearance of a hyperpolarisationactivated inward current in TCs during labour might modulate the activity of SMCs, not as pacemaker cells but rather as timing control cells, possibly acting on the duration between successive contractions. This is in agreement with previous findings (Popescu et al. 2006, Cretoiu et al. 2011, 2012a) that imatinib inhibits the frequency and amplitude of spontaneous myometrial
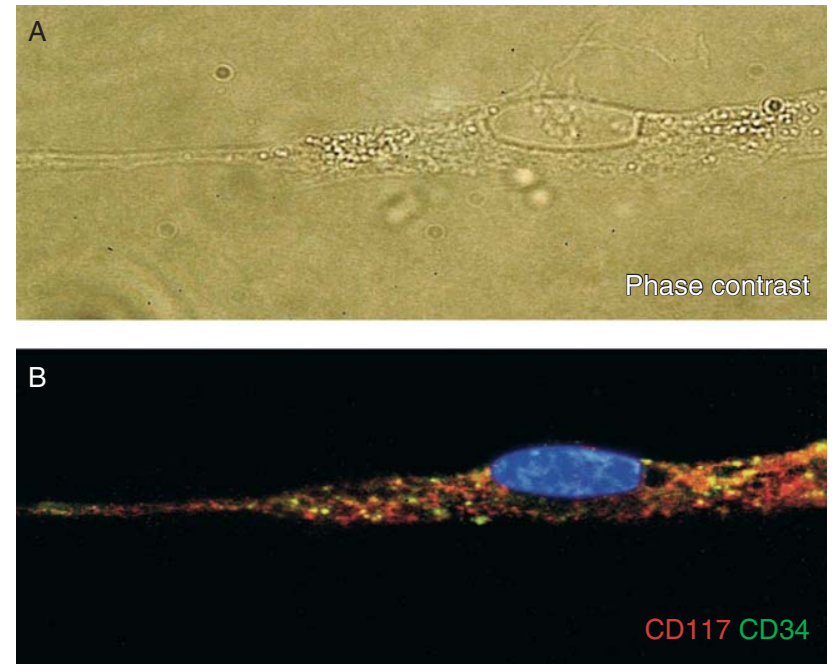

Figure 8 Human myometrium cells in culture (the second passage): (A) control phase-contrast microscopy and (B) IF for c-kit and CD34 (red and green respectively) of the same microscopic fields. One can observe that TCs co-express c-kit and CD34 in the same area (yellow). Original magnification $60 \times$, nuclear counterstaining with Hoechst 33342 (blue). 

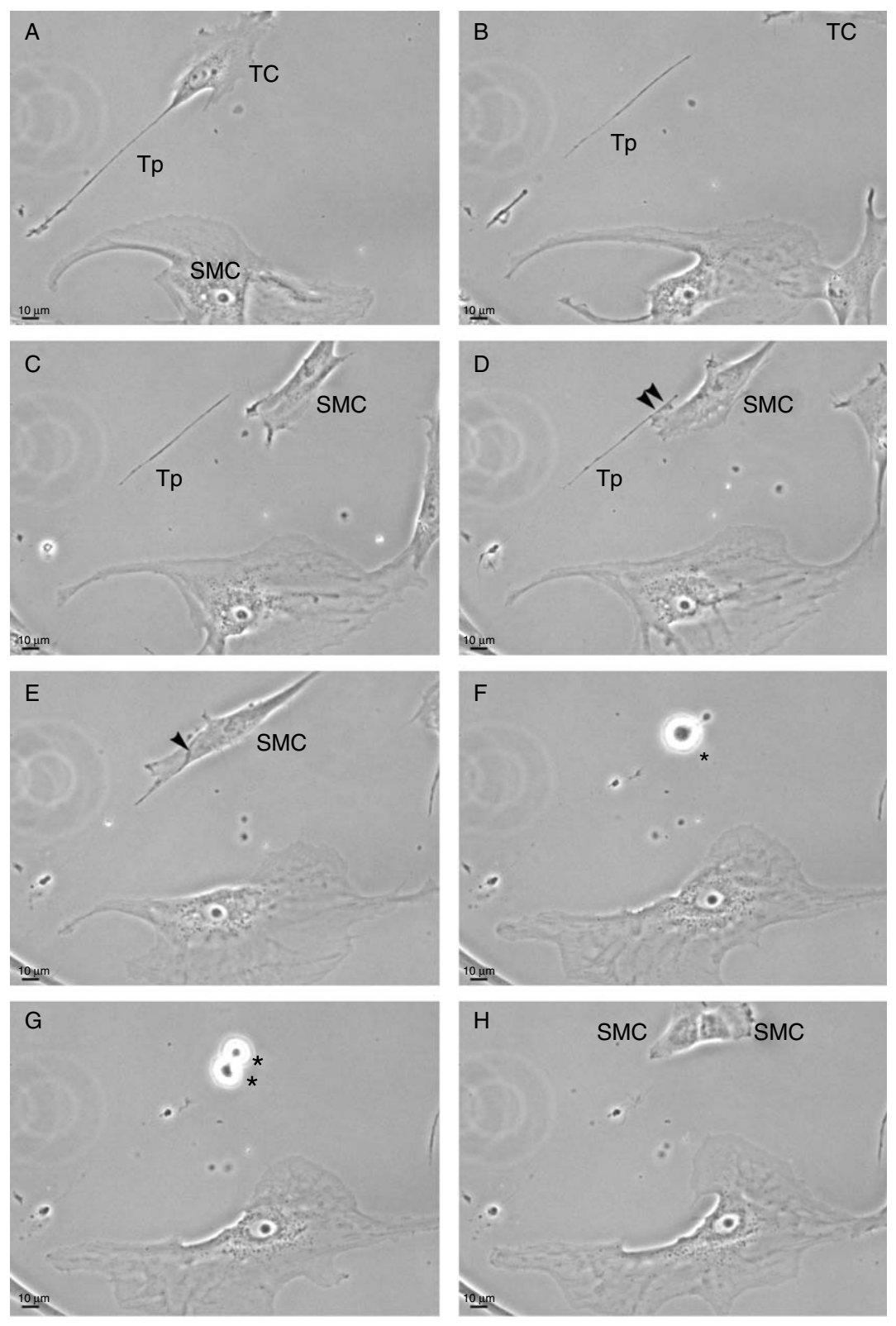

Figure 9 Human non-pregnant myometrium. Cell culture, the first passage. (A, B, C, D, E, F, G and H) Successive snapshots chosen from a time-lapse videomicroscopy recording. (A and B) A TC is moving towards the upper part of the microscopic field leaving behind a very long telopode. Immediately after, an SMC can be seen approaching the telopode (C) and establishing connections with it (D, arrowheads). Soon the SMC will twirl around the Tp (using it as guiding wire) (E) and then will detach from the dish ( $\mathrm{F}$, asterisk), divide $(\mathrm{G}$, double asterisk) and then reattach $(\mathrm{H})$. Objective, $20 \times$. Scale bar $10 \mu \mathrm{m}$. contractions, possibly by interfering with TCs' electrical modulator properties. Extensive electrophysiological studies and single-cell qRT-PCR are necessary in order to understand the origin and the exact role of these currents in the myometrium physiology.

TCs could act as supporting cells for tissue organisation at least in some organs (Bani et al. 2010, Popescu \& Faussone-Pellegrini 2010, Gherghiceanu \& Popescu 2011, Rusu et al. 2012b). Recent evidence suggests that TCs might even play a role in neo-angiogenesis (Manole et al. 2011).

TCs could have the capacity to receive/generate molecular signals from/to other cells which can influence the surrounding myocytes by juxta/paracrine mechanisms (Popescu et al. 2006, Cretoiu et al. 2011).
Figure 9 (and Supplementary Video 1) supports this, indicating that TCs (at least in vitro) intermediate by their Tps a cellular-driven guidance for neighbouring cells.

In addition, Tps establish physical contacts with nerve endings, blood vessels and different types of progenitor cells (Gherghiceanu \& Popescu 2011, Popescu et al. 2011a, 2011b, Zheng et al. 2012a), as well as with each other (Gherghiceanu \& Popescu 2012), suggesting a role of TCs in intercellular signalling. Direct membraneto-membrane homocellular contacts between Tps and the release of exosomes (60-100 nm vesicles) and SMVs (diameters: $250-350 \mathrm{~nm}$ up to $1 \mu \mathrm{m}$ ) from Tps suggested TCs' involvement in intercellular signalling. We can assume the existence of a paracrine and/or juxtacrine secretion of small molecules and long-distance 

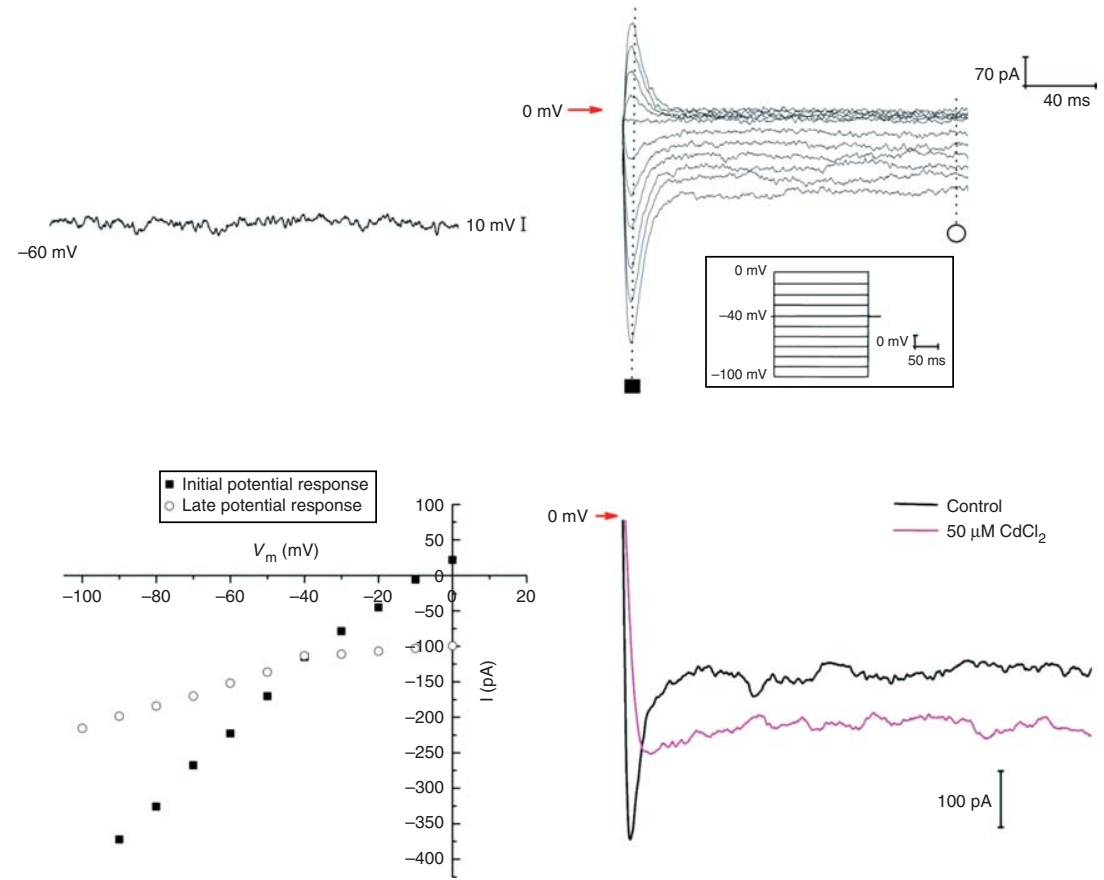

Figure 10 Patch-clamp recordings on TCs from human non-pregnant myometrium. (A) A zero current-clamp recording of the resting potential from a TC. (B) Hyperpolarisation-activated inward currents generated by $200 \mathrm{~ms}$ duration pulses from -100 to $0 \mathrm{mV}$, starting from a holding potential of $-40 \mathrm{mV}$. (C) Current-voltage plot for the current records presented in (B) showing a slight inward rectification. (D) Calcium dependence of the hyperpolarisation-activated inward currents tested by extracellular cadmium $(50 \mu \mathrm{M})$ application.

signalling by SMVs. Also we can hypothesise a possible involvement in horizontal transfer of important macromolecules among neighbouring cells (Ramachandran \& Palanisamy 2012). The release of secreted extracellular vesicles could be seen as a way for sending macromolecular signals (e.g. microRNAs, Cismasiu et al. (2011)) or in the formation of morphogenetic gradients for tissue patterning during development.

Future TCs immunophenotyping could bring new evidence regarding a possible involvement in myometrial regeneration. At present, there are a very few data regarding the existence of myometrial regenerative cells named adult myometrial precursors (AMPs; Gálvez et al. 2010) or muscle-derived stem cells (Jun et al. 2012). They are in fact very similar to TCs expressing CD117 and CD34, supporting our team's hypothesis regarding TCs in the interstitium of skeletal muscle, lungs and skin (Popescu et al. 2011a, 2011b, Ceafalan et al. 2012, Suciu et al. 2012). Gálvez suggested that AMPs could constitute a new source of adult stem cells. AMPs seem to have superior features to other known adult stem cells. AMPs can form new vessels and can regenerate the uterine lining after wound healing, reconstructing the uterine muscular architecture suggesting that their use holds great promise for regenerative medicine, drug development and basic research (Gálvez et al. 2010) in concordance with similar suggested roles of TCs (Horch et al. 2012).

Considering our previous reports which demonstrated stromal contacts between TCs and immune cells (eosinophils, macrophages and plasma cells) in rat myometrium (Popescu et al. 2005b), we can hypothesise a role in immune surveillance. Leucocytes are known to be crucial for pregnancy maintenance and for the mechanism of uterine activation during labour (Thomson et al. 1999, Keski-Nisula et al. 2003, Shynlova et al. 2008). In our opinion TCs, myocytes and leucocytes could work together in pregnancy maintenance or in the onset of labour.

The importance of TCs in pathology cannot be overlooked since it was recently suggested that they might represent the common cell of origin of a variety of stromal tumours, generating extragastrointestinal stromal tumours and even perivascular epithelioid cell tumours (Ardeleanu \& Bussolati 2011, Padhi et al. 2013). CD117positive cells, similar to TCs, were suggested to prevent premature uterine contraction in mid-gestational period (Horn et al. 2012).

In conclusion TCs should not be ignored further in understanding the correlation of structure/function in pregnant and non-pregnant myometrium.

\section{Materials and Methods}

\section{Human myometrial tissue samples}

Biopsies of human non-pregnant myometrium were obtained from hysterectomy specimens (benign indications) of premenopausal women $(n=7)$. Biopsies from uteri of pregnant women (between 38 and 40 weeks of gestation) were obtained at the time of elective caesarean section (pre-labour at 38 weeks gestational age, $n=5$ ) and in labour (delivering at term, 40 weeks gestational age, $n=4)$. The exclusion criteria used in the selection of research subjects were not to have associated medical conditions or treatment history. To avoid endometrium contamination of the cell cultures the uterine mucosa was removed. At the time of caesarean delivery, a strip of uterine 
smooth muscle was taken from the upper margin (in the midline) of the lower segment transverse incision. All tissue samples were obtained (after informed written consent from each woman). The protocol for this study was approved by the Bioethics Committee of the University of Medicine and Pharmacy, Bucharest, in accordance with The Code of Ethics of the Declaration of Helsinki.

\section{Electron microscopy}

Small tissue samples (about $1 \mathrm{~mm}^{3}$ ) of human pregnant and non-pregnant myometrium were immersed in fresh $4 \%$ glutaraldehyde for $4 \mathrm{~h}$ at $4{ }^{\circ} \mathrm{C}$. After fixation the tissues were washed overnight in $0.1 \mathrm{M}$ sodium cacodylate buffer at $4{ }^{\circ} \mathrm{C}$ post-fixed with $1 \%$ potassium ferrocyanide and $1 \%$ osmium tetroxide mixture in $0.05 \mathrm{M}$ sodium cacodylate buffer $(\mathrm{pH} 7.4)$ at room temperature for 60 min dehydrated in graded ethanol and propylene oxide and embedded in Epon 812. Control semi-thin sections $(<1 \mu \mathrm{m})$ were stained with $1 \%$ toluidine blue and examined by light microscopy (Nikon Eclipse E600). Representative photomicrographs were taken using Nikon Plan 40x and Nikon Plan Flour 100x/1.30 oil objectives. Ultrathin sections $(60 \mathrm{~nm})$ were cut using an MT-7000 ultramicrotome (Research and Manufacturing Company, Inc., Tucson, AZ, USA), mounted on 50-mesh grids and double stained with uranyl acetate and lead citrate. The grids were examined under a Phillips 301 electron microsope or a CM 12 Philips electron microscope at an acceleration voltage of $60 \mathrm{kV}$. Images from three or four randomly selected regions per sample were captured using an Olympus Morada CCD camera (16 bit, 11 megapixels).

\section{Bidimensional reconstructions}

In order to achieve a bidimensional reconstruction of TCs, successive images of microscopic fields were captured at high magnification $(98000 \times)$, then aligned with each other and merged to form a collage. Alignment and merging were done using Adobe Photoshop software (Adobe Systems).

\section{Digital colouring of electron micrographs}

EM images were digitally coloured to increase the visual contrast between several structures: TCs, Tps and microvesicles. The purpose of such a technique is to make them more visible for the untrained eye. Contours of all structures have been manually traced in Adobe Photoshop software (Adobe Systems) using a Wacom digital tablet (Wacom Europe $\mathrm{GmbH}$, Krefeld, Germany).

\section{Morphometry and statistics}

Two-dimensional concatenations of sequenced micrographs were analysed for quantitative data. Microscopic measurements were performed by two different researchers using 50 randomly selected structures/images. The data are represented as mean $\pm 5 \% \mathrm{Cl}$. Box and whisker diagrams were used to graphically depict the medians and the quartiles of extracellular vesicles released by Tps. Methods of statistical analysis are included in relevant figure legends. For comparisons $t$-test and ANOVA test were used and $P<0.05$ was regarded as significant.

\section{Immunohistochemistry}

Paraffin-embedded $4 \mu \mathrm{m}$-thick sections of myometrial smooth muscle were stained using the following antibodies: anti-c-kit (1:100, polyclonal; Dako, Glostrup, Denmark) and CD34, monoclonal, 1:100, clone QBEND10 (Biogenex, San Ramon, CA, USA) according to the avidin-biotin peroxidase complex method, as previously reported (Ciontea et al. 2005). Negative controls were done using an irrelevant primary antibody or replacing the secondary antibody with PBS. A positive control (a tissue known to express the marker in question) was used for every specific immunohistochemical stain. To ensure the reliability of experimental study internal quality control of immunohistochemical techniques was performed as a part of an implemented and certified quality assurance system (ISO 1239001/2001). Sections were counterstained with Mayer's haematoxylin, examined and photographed under a Nikon Eclipse 600 microscope.

\section{Myometrial cells in culture}

Human myometrial samples were collected into sterile tubes containing DMEM supplemented with foetal bovine serum (FBS) $2 \%$, HEPES (1.5 mM) as well as $10000 \mathrm{IU} / \mathrm{ml}$ penicillin, $0.2 \mathrm{mg} / \mathrm{ml}$ streptomycin and $0.50 \mu \mathrm{g} / \mathrm{ml}$ amphotericin (Sigma Chemical), placed on ice and transported to the cell culture laboratory. Samples were processed within $30 \mathrm{~min}$ from surgery and rinsed with sterile DMEM. The smooth muscle tissue was minced into $0.5-\mathrm{mm}$ pieces, subsequently washed and incubated with gentle agitation for $30 \mathrm{~min}$, at $37^{\circ} \mathrm{C}$, with collagenase la (Sigma Chemical) $10 \mathrm{mg} / \mathrm{ml}$ and DNase I $(0.1 \mathrm{~nm} / \mathrm{mg})$ in DMEM supplemented with FBS $10 \%$, HEPES $1.5 \mathrm{mM}, 10000 \mathrm{IU} / \mathrm{ml}$ penicillin, $0.1 \mathrm{mg} / \mathrm{ml}$ streptomycin and $0.25 \mu \mathrm{g} / \mathrm{ml}$ amphotericin. The dispersed cells were separated from non-digested tissue by filtration through a cell strainer $(100 \mu \mathrm{m})$, collected by centrifugation of the filtrate at $250 \mathrm{~g}$ for $10 \mathrm{~min}$, at room temperature $\left(20^{\circ} \mathrm{C}\right)$ and suspended in culture medium. Cells were distributed in $25-\mathrm{cm}^{2}$ plastic culture lasks (BD Falcon, San Jose, CA, USA), or on glass coverslips into 24-well plates (BD Labware, San Jose, CA, USA) at a density of $5 \times 10^{4}$ cells $/ \mathrm{cm}^{2}$. Medium was changed every $48 \mathrm{~h}$. Cells were maintained at $37{ }^{\circ} \mathrm{C}$ in a humidified atmosphere $\left(5 \% \mathrm{CO}_{2}\right.$ in air) until becoming semi-confluent (usually 4 days after plating) when the cells were detached using $0.25 \%$ trypsin and $2 \mathrm{mM}$ EDTA and re-plated at the same density of $5 \times 10^{4}$ cells $/ \mathrm{cm}^{2}$. Experiments were performed in primary cultures and between passages 1 and 6 . Cells were examined and photographed under a Nikon inverted TE200 microscope equipped with a Nikon DN-5digital camera.

\section{Janus green B vital staining}

Cells in primary culture were stained for $30 \mathrm{~min}$ in $0.02 \%$ Janus green B (Sigma Chemical) using a protocol previously 
described (Ciontea et al. 2005) and examined under a heated-object-stage inverted Nikon TE200 microscope and photographed.

\section{Immunofluorescence}

Immunofluorescent staining of cell cultures was performed using a protocol previously described by Ciontea et al. (2005). Primary antibodies: c-kit (clone Ab81, working dilution 1:100; Santa Cruz Biotechnology) and CD34 (clone 8G12, FITCconjugated working dilution 1:10; BD Immunocytometry Systems, San Jose, CA, USA) were applied for $4 \mathrm{~h}$, at room temperature. Polyclonal FITC-labelled goat anti-mouse antibodies (working dilution 1:300; BD Pharmingen, San Jose, CA, USA) were used to detect the primary immune reaction. For double-staining experiments, the second reaction was detected using monoclonal rat anti-mouse biotinylated antibodies (1:200, clone A85-1; BD Pharmingen) and streptavidin - Alexa Fluor 546 (working dilution 1:200; Molecular Probes, Eugene, OR, USA). The nuclei were counterstained with $1 \mu \mathrm{g} / \mathrm{ml}$ Hoechst 33342 (Sigma Chemical), and the samples were examined under a Nikon TE300 microscope equipped with a Nikon DX1 camera, Nikon Plan Apo $40 \times$ and $60 \times$ oil objectives, and the appropriate fluorescence filters. Negative controls were prepared following the same protocol, but omitting the primary antibodies.

\section{Time-lapse videomicroscopy}

Cell culture (non-pregnant myometrium, first passage) plated in $35-\mathrm{cm}^{2}$ Petri dishes was transferred into the controlled environment of Nikon Biostation IM (Nikon Instruments Europe B.V., Amstelveen, The Netherlands). Cells' behaviour was monitored every $5 \mathrm{~min}$ for $48 \mathrm{~h}$ by time-lapse videomicroscopy. The video information was digitally recorded at $800 \times 600$ pixels. The video runs at four frames per second $-10 \mathrm{~s}$ of running video time corresponds to about $200 \mathrm{~min}$ of recording time.

\section{Patch-clamp technique}

Whole-cell membrane currents were recorded on TCs from non-pregnant uterus. Electrodes were made by pulling borosilicate glass capillaries (GC150F; Harvard Apparatus, Edenbridge, Kent, UK) and heat polished to a resistance of 3-4 M . Capacitive transients were cancelled. Series resistance was compensated in a range of $70-80 \%$. Inward-activated currents were recorded under the voltage-clamp mode, with the membrane potential held at $-40 \mathrm{mV}$, using a WPC-100 amplifier (ESF Electronic, Göttingen, Germany). The perfusion was performed with an MPS-2 (World Precision Instruments, Sarasota, FL, USA) system, with the tip placed at $\sim 100 \mu \mathrm{m}$ from the cell. Membrane currents were low-pass filtered at $3 \mathrm{kHz}(-3 \mathrm{~dB}, 3$ pole Bessel) and sampled with a Digidata 1322 data acquisition system (Axon Instruments, Foster City, CA, USA) using pClamp 8.1 software in gap-free mode. All electrophysiological experiments were performed at room temperature $\left(25^{\circ} \mathrm{C}\right)$. The extracellular solution contained (mM): $\mathrm{BaCl}_{2} 20, \mathrm{CsCl} 85, \mathrm{MgCl}_{2}$ 1, HEPES 10, TEA-Cl 40, glucose 5, $\mathrm{pH} 7.4$ (with $\mathrm{CsOH}$ ). The pipette solution contained (mM): $\mathrm{CsCl} 120, \mathrm{NaCl} 10$, EGTA 10, HEPES 10, $\mathrm{MgCl}_{2} 3.45$, $\mathrm{Na}_{2}$ ATP 5, $\mathrm{Na}_{2}$ GTP 0.1, pH 7.2 (with $\left.\mathrm{CsOH}\right) . \mathrm{CdCl}_{2}(50 \mu \mathrm{M})$ was applied $30 \mathrm{~s}$ before starting the voltage-clamp record. Nifedipine $(10 \mu \mathrm{M})$ was applied $1 \mathrm{~min}$ before starting the voltage-clamp record. From a holding potential of $-40 \mathrm{mV}$, currents were elicited by $200 \mathrm{~ms}$ depolarising steps of $10 \mathrm{mV}$, from $-100 \mathrm{mV}$ up to $0 \mathrm{mV}$. Data were analysed in Clampfit 10.2 (Axon Instruments) and plotted in Origin 8.6.

\section{Supplementary data}

This is linked to the online version of the paper at http://dx.doi. org/10.1530/REP-12-0369.

\section{Declaration of interest}

The authors declare that there is no conflict of interest that could be perceived as prejudicing the impartiality of the research reported.

\section{Funding}

This work was partially supported (for SMC) by the Sectorial Operational Program Human Resources Development (SOP HRD), financed from the European Social Fund and by the Romanian Government under the contract number POSDRU/89/1.5/S/64109. A Marin was supported by the strategic grant POSDRU/89/1.5/S/58852, Project 'Postdoctoral program for training scientific researchers' co-financed by the European Social Found within the Sectorial Operational Program Human Resources Development 2007-2013. B M Radu was supported by Verona Nanomedicine initiative grant financed by the Cariverona Foundation. This project was partially conducted through the program Partnerships in priority areas - PN II, developed with the support of ANCS, CNDI UEFISCDI, project no. 82/2012.

\section{Acknowledgements}

We are grateful to Mrs Maria Buzatu, Mrs Geanina Haralambie and Mr T Regalia for their expert technical assistance.

\section{References}

Allix S, Reyes-Gomez E, Aubin-Houzelstein G, Noël D, Tiret L, Panthier JJ \& Bernex F 2008 Uterine contractions depend on KIT-positive interstitial cells in the mouse: genetic and pharmacological evidence. Biology of Reproduction 79 510-517. (doi:10.1095/biolreprod.107.066373)

Ardeleanu C \& Bussolati G 2011 Telocytes are the common cell of origin of both PEComas and GISTs: an evidence-supported hypothesis. Journal of Cellular and Molecular Medicine 15 2569-2574. (doi:10.1111/j.15824934.2011.01461.x)

Bani D, Formigli L, Gherghiceanu M \& Faussone-Pellegrini MS 2010 Telocytes as supporting cells for myocardial tissue organization in developing and adult heart. Journal of Cellular and Molecular Medicine 14 2531-2538. (doi:10.1111/j.1582-4934.2010.01119.x)

Barile L \& Lionetti V 2012 Prometheus's heart: what lies beneath. Journal of Cellular and Molecular Medicine 16 228-236. (doi:10.1111/j.15824934.2011.01487.x) 
Bigsby RM 2002 Control of growth and differentiation of the endometrium: the role of tissue interactions. Annals of the New York Academy of Sciences 955 110-117. (doi:10.1111/j.1749-6632.2002.tb02771.x)

Bojin FM, Gavriliuc OI, Cristea MI, Tanasie G, Tatu CS, Panaitescu C \& Paunescu V 2011 Telocytes within human skeletal muscle stem cell niche. Journal of Cellular and Molecular Medicine 15 2269-2272. (doi:10.1111/j.1582-4934.2011.01386.x)

Cantarero I, Luesma MJ \& Junquera C 2011 The primary cilium of telocytes in the vasculature: electron microscope imaging. Journal of Cellular and Molecular Medicine 15 2594-2600. (doi:10.1111/j.1582-4934.2011. 01312.x)

Cantarero Carmona I, Luesma Bartolomé MJ \& Junquera Escribano C 2011 Identification of telocytes in the lamina propria of rat duodenum: transmission electron microscopy. Journal of Cellular and Molecular Medicine 15 26-30. (doi:10.1111/j.1582-4934.2010.01207.x)

Ceafalan L, Gherghiceanu M, Popescu LM \& Simionescu O 2012 Telocytes in human skin - are they involved in skin regeneration? Journal of Cellular and Molecular Medicine 16 1405-1420. (doi:10.1111/j.15824934.2012.01580.x)

Ciontea SM, Radu E, Regalia T, Ceafalan L, Cretoiu D, Gherghiceanu M, Braga RI, Malincenco M, Zagrean L, Hinescu ME et al. 2005 c-kit immunopositive interstitial cells (Cajal-type) in human myometrium. Journal of Cellular and Molecular Medicine 9 407-420. (doi:10.1111/ j.1582-4934.2005.tb00366.x)

Cismasiu VB, Radu E \& Popescu LM 2011 miR-193 expression differentiates telocytes from other stromal cells. Journal of Cellular and Molecular Medicine 15 1071-1074. (doi:10.1111/j.1582-4934.2011.01325.x)

Cozzi E, Ackerman KG, Lundequist A, Drazen JM, Boyce JA \& Beier DR 2011 The naive airway hyperresponsiveness of the $A / J$ mouse is Kitmediated. PNAS 108 12787-12792. (doi:10.1073/pnas.1106582108)

Cretoiu D, Ciontea SM, Popescu LM, Ceafalan L \& Ardeleanu C 2006 Interstitial Cajal-like cells (ICLC) as steroid hormone sensors in human myometrium: immunocytochemical approach. Journal of Cellular and Molecular Medicine 10 789-795. (doi:10.1111/j.1582-4934.2006.tb00438.x)

Cretoiu SM, Simionescu AA, Caravia L, Curici A, Cretoiu D \& Popescu LM 2011 Complex effects of imatinib on spontaneous and oxytocin-induced contractions in human non-pregnant myometrium. Acta Physiologica Hungarica 98 329-338. (doi:10.1556/APhysiol.98.2011.3.10)

Cretoiu SM, Cretoiu D, Simionescu AA \& Popescu LM 2012a Telocytes in human fallopian tube and uterus express estrogen and progesterone receptors. In Sex Steroids. pp. 91-114. Ed SM Kahn. Rijeka: Intech. ISBN 978-953-307-857-1.

Cretoiu D, Cretoiu SM, Simionescu AA \& Popescu LM 2012b Telocytes, a distinct type of cell among the stromal cells present in the lamina propria of jejunum. Histology and Histopathology 27 1067-1078.

Cretoiu SM, Cretoiu D \& Popescu LM 2012c Human myometrium the ultrastructural 3D network of telocytes. Journal of Cellular and Molecular Medicine 16 2844-2849. (doi:10.1111/j.1582-4934.2012. 01651.x)

Cunha GR, Cooke PS \& Kurita T 2004 Role of stromal-epithelia interactions in hormonal responses. Archives of Histology and Cytology 67 417-434. (doi:10.1679/aohc.67.417)

Díaz-Flores L, Gutiérrez R, Sáez FJ, Díaz-Flores L Jr \& Madrid JF 2013 Telocytes in neuromuscular spindles. Journal of Cellular and Molecular Medicine 17. (doi:10.1111/jcmm.12015)

Duquette RA, Shmygol A, Vaillant C, Mobasheri A, Pope M, Burdyga T \& Wray S 2005 Vimentin-positive, c-kit-negative interstitial cells in human and rat uterus: a role in pacemaking? Biology of Reproduction $\mathbf{7 2}$ 276-283. (doi:10.1095/biolreprod.104.033506)

El-Bassouny DR 2012 Ultrastructural study of the adult albino rat parotid gland with special reference to the role of stromal telocytes. Egyptian Journal of Histology 35 761-772. (doi:10.1097/01.EHX.0000421520. 41159.03)

Faussone-Pellegrini MS 2009 Interplay among enteric neurons, interstitial cells of Cajal, resident and not resident connective tissue cells. Journal of Cellular and Molecular Medicine 13 1191-1192. (doi:10.1111/j.15824934.2009.00814.x)

Faussone-Pellegrini MS \& Bani D 2010 Relationships between telocytes and cardiomyocytes during pre- and post-natal life. Journal of Cellular and Molecular Medicine 14 1061-1063. (doi:10.1111/j.1582-4934.2010. 01074.x)
Faussone-Pellegrini MS \& Popescu LM 2011 Telocytes. Biomolecular Concepts 2 481-489.

Gálvez BG, Martín NS, Salama-Cohen P, Lazcano JJ, Coronado MJ, Lamelas ML, Alvarez-Barrientes A, Eiró N, Vizoso F \& Rodríguez C 2010 An adult myometrial pluripotential precursor that promotes healing of damaged muscular tissues. In Vivo 24 431-441.

Gevaert T, De Vos R, Everaerts W, Libbrecht L, Van Der Aa F, van den Oord J, Roskams T \& De Ridder D 2011 Characterization of upper lamina propria interstitial cells in bladders from patients with neurogenic detrusor overactivity and bladder pain syndrome. Journal of Cellular and Molecular Medicine 15 2586-2593. (doi:10.1111/j.1582-4934.2011. 01262.x)

Gevaert T, De Vos R, Van Der Aa F, Joniau S, van den Oord J, Roskams T \& De Ridder D 2012 Identification of telocytes in the upper lamina propria of the human urinary tract. Journal of Cellular and Molecular Medicine 16 2085-2093. (doi:10.1111/j.1582-4934.2011.01504.x)

Gherghiceanu M \& Popescu LM 2010 Cardiomyocyte precursors and telocytes in epicardial stem cell niche: electron microscope images. Journal of Cellular and Molecular Medicine 14 871-877. (doi:10.1111/ j.1582-4934.2010.01060.x)

Gherghiceanu M \& Popescu LM 2011 Heterocellular communication in the heart: electron tomography of telocyte-myocyte junctions. Journal of Cellular and Molecular Medicine 15 1005-1011. (doi:10.1111/j.15824934.2011.01299.x)

Gherghiceanu M \& Popescu LM 2012 Cardiac telocytes their junctions and functional implications. Cell and Tissue Research 348 265-279. (doi:10.1007/s00441-012-1333-8)

Gherghiceanu M, Manole CG \& Popescu LM 2010 Telocytes in endocardium: electron microscope evidence. Journal of Cellular and Molecular Medicine 14 2330-2334. (doi:10.1111/j.1582-4934.2010.01133.x)

Gravina FS, Parkington HC, Kerr KP, de Oliveira RB, Jobling P, Coleman HA, Sandow SL, Davies MM, Imtiaz MS \& van Helden DF 2010 Role of mitochondria in contraction and pacemaking in the mouse uterus. British Journal of Pharmacology 161 1375-1390. (doi:10.1111/ j.1476-5381.2010.00949.x)

Hamilton S, Oomomian Y, Stephen G, Shynlova O, Tower CL, Garrod A, Lye SJ \& Jones RL 2012 Macrophages infiltrate the human and rat decidua during term and preterm labor: evidence that decidual inflammation precedes labor. Biology of Reproduction 86 39. (doi:10.1095/biolreprod. 111.095505)

Harhun M, Gordienko D, Kryshtal D, Pucovský V \& Bolton T 2006 Role of intracellular stores in the regulation of rhythmical $\left[\mathrm{Ca}^{2+}\right]_{i}$ changes in interstitial cells of Cajal from rabbit portal vein. Cell Calcium $\mathbf{4 0}$ 287-298. (doi:10.1016/j.ceca.2006.04.018)

Hatta K, Huang ML, Weisel RD \& Li RK 2012 Culture of rat endometrial telocytes. Journal of Cellular and Molecular Medicine 16 1392-1396. (doi:10.1111/j.1582-4934.2012.01583.x)

Hinescu ME, Ardeleanu C, Gherghiceanu M \& Popescu LM 2007 Interstitial Cajal-like cells in human gallbladder. Journal of Molecular Histology 38 275-284. (doi:10.1007/s10735-007-9099-0)

Hinescu ME, Popescu LM, Gherghiceanu M \& Faussone-Pellegrini MS 2008 Interstitial Cajal-like cells in rat mesentery: an ultrastructural and immunohistochemical approach. Journal of Cellular and Molecular Medicine 12 260-270. (doi:10.1111/j.1582-4934.2008. 00226.x)

Hinescu ME, Gherghiceanu M, Suciu L \& Popescu LM 2011 Telocytes in pleura: two- and three-dimensional imaging by transmission electron microscopy. Cell and Tissue Research 343 389-397. (doi:10.1007/ s00441-010-1095-0)

Horch RE, Kneser U, Polykandriotis E, Schmidt VJ, Sun J \& Arkudas A 2012 Tissue engineering and regenerative medicine - where do we stand? Journal of Cellular and Molecular Medicine 16 1157-1165. (doi:10.1111/j.1582-4934.2012.01564.x)

Horn LC, Meinel A \& Hentschel B 2012 c-kit/CD 117 positive cells in the myometrium of pregnant women and those with uterine endometriosis. Archives of Gynecology and Obstetrics 286 105-107. (doi:10.1007/ s00404-012-2220-y)

Huang X, Zhao D, Wang ZY, Zhang ML, Yan ZQ, Han YF, Xu WX \& Jiang ZL 2010 The properties of spontaneous transient inward currents of interstitial cells in rabbit portal vein. European Journal of Pharmacology 643 63-69. (doi:10.1016/j.ejphar.2010.06.011) 
Hutchings G, Williams O, Cretoiu D \& Ciontea SM 2009 Myometrial interstitial cells and the coordination of myometrial contractility. Journal of Cellular and Molecular Medicine 13 4268-4282. (doi:10.1111/j.1582-4934.2009.00894.x)

Jun CR, Lee JY \& Cho HH 2012 Muscle-derived stem cells and smooth muscle healing in a rat model of uterine injury. International Journal of Gynecology and Obstetrics 116 265-266. (doi:10.1016/j.ijgo. 2011.10.013)

Keski-Nisula LT, Aalto ML, Kirkinen PP, Kosma VM \& Heinonen ST 2003 Myometrial inflammation in human delivery and its association with labor and infection. American Journal of Clinical Pathology 120 217-224. (doi:10.1309/KC6KDTX98LFYB3J7)

Kim YC, Suzuki H, Xu WX, Choi W, Kim SH \& Lee SJ $2009 \mathrm{Ca}^{2+}$-activated $\mathrm{K}^{+}$current in freshly isolated c-Kit positive cells in guinea-pig stomach. Journal of Korean Medical Science 24 384-391. (doi:10.3346/jkms. 2009.24.3.384)

Kim BJ, Nam JH \& Kim SJ 2011 Effects of transient receptor potential channel blockers on pacemaker activity in interstitial cells of Cajal from mouse small intestine. Molecules and Cells 32 153-160. (doi:10.1007/ s10059-011-1019-1)

Koh S, Koh B, Roy R, Hollywood M, Thornbury K, McHale N, Sergeant G, Hatton W, Ward S \& Sanders K 2012 PDGFR $\alpha$ cells in mouse urinary bladder: a new class of interstitial cells. Journal of Cellular and Molecular Medicine 16 691-700. (doi:10.1111/j.1582-4934.2011.01506.x)

Kostin S 2010 Myocardial telocytes: a specific new cellular entity. Journal of Cellular and Molecular Medicine 14 1917-1921. (doi:10.1111/j.15824934.2010.01111.x)

Laflamme MA \& Murry CE 2011 Heart regeneration. Nature 473 326-335. (doi:10.1038/nature10147)

Lee H, Koh BH, Peri LE, Sanders KM \& Koh SD 2012 Functional expression of SK channels in murine detrusor PDGFR $\alpha+$ cells. Journal of Physiology 591 503-513. (doi:10.1113/jphysiol.2012.241505)

Liehn EA, Postea O, Curaj A \& Marx N 2011 Repair after myocardial infarction, between fantasy and reality: the role of chemokines. Journal of the American College of Cardiology 58 2357-2362. (doi:10.1016/j.jacc. 2011.08.034)

Mandache E, Gherghiceanu M, Macarie C, Kostin S \& Popescu LM 2010 Telocytes in human isolated atrial amyloidosis: ultrastructural remodelling. Journal of Cellular and Molecular Medicine 14 2739-2747. (doi:10.1111/j.1582-4934.2010.01200.x)

Manole CG, Cismasiu V, Gherghiceanu M \& Popescu LM 2011 Experimental acute myocardial infarction: telocytes involvement in neo-angiogenesis. Journal of Cellular and Molecular Medicine 15 2284-2296. (doi:10.1111/j.1582-4934.2011.01449.x)

Nicolescu MI \& Popescu LM 2012 Telocytes in the interstitium of human exocrine pancreas: ultrastructural evidence. Pancreas 41 949-956. (doi:10.1097/MPA.0b013e31823fbded)

Nicolescu MI, Bucur A, Dinca O, Rusu MC \& Popescu LM 2012 Telocytes in parotid glands. Anatomical Record 295 378-385. (doi:10.1002/ ar.21540)

Osman I, Young A, Ledingham MA, Thomson AJ, Jordan F, Greer IA \& Norman JE 2003 Leukocyte density and pro-inflammatory cytokine expression in human fetal membranes, decidua, cervix and myometrium before and during labor at term. Molecular Human Reproduction 9 41-45. (doi:10.1093/molehr/gag001)

Padhi S, Sarangi R \& Mallick S 2013 Pancreatic extragastrointestinal stromal tumors, interstitial Cajal like cells, and telocytes. Journal of the Pancreas 14 1-14. (doi:10.6092/1590-8577/1293)

Parsons SP \& Huizinga JD 2010 Transient outward potassium current in ICC. American Journal of Physiology. Gastrointestinal and Liver Physiology 298 G456-G466. (doi:10.1152/ajpgi.00340.2009)

Pieri L, Vannucchi MG \& Faussone-Pellegrini MS 2008 Histochemical and ultrastructural characteristics of an interstitial cell type different from ICCs and resident in the muscle coat of human gut. Journal of Cellular and Molecular Medicine 12 1944-1955. (doi:10.1111/j.1582-4934. 2008.00461.x)

Popescu LM \& Faussone-Pellegrini MS 2010 TELOCYTES - a case of serendipity: the winding way from interstitial cells of Cajal (ICC), via interstitial Cajal-like cells (ICLC) to TELOCYTES. Journal of Cellular and Molecular Medicine 14 729-740. (doi:10.1111/j.1582-4934.2010. 01059.x)
Popescu LM \& Nicolescu MI 2013 Telocytes and stem cells. In Resident Stem Cells and Regenerative Therapy, pp 205-231. Eds RC dos Santos Goldenberg \& AC Campos de Carvalho. Oxford: Academic Press.

Popescu LM, Ciontea SM, Cretoiu D, Hinescu ME, Radu E, Ionescu N, Ceausu M, Gherghiceanu M, Braga RI, Vasilescu F et al. 2005a Novel type of interstitial cell (Cajal-like) in human fallopian tube. Journal of Cellular and Molecular Medicine 9 479-523. (doi:10.1111/j.1582-4934. 2005.tb00376.x)

Popescu LM, Gherghiceanu M, Cretoiu D \& Radu E 2005b The connective connection: interstitial cells of Cajal (ICC) and ICC-like cells establish synapses with immunoreactive cells. Electron microscope study in situ. Journal of Cellular and Molecular Medicine 9 714-730. (doi:10.1111/ j.1582-4934.2005.tb00502.x)

Popescu LM, Vidulescu C, Curici A, Caravia L, Simionescu AA, Ciontea SM \& Simion S 2006 Imatinib inhibits spontaneous rhythmic contractions of human uterus and intestine. European Journal of Pharmacology 546 177-181. (doi:10.1016/j.ejphar.2006.06.068)

Popescu LM, Ciontea SM \& Cretoiu D 2007 Interstitial Cajal-like cells in human uterus and fallopian tube. Annals of the New York Academy of Sciences 1101 139-165. (doi:10.1196/annals.1389.022)

Popescu LM, Manole CG, Gherghiceanu M, Ardelean A, Nicolescu MI, Hinescu ME \& Kostin S 2010 Telocytes in human epicardium. Journal of Cellular and Molecular Medicine 14 2085-2093. (doi:10.1111/j.15824934.2010.01129.x)

Popescu LM, Gherghiceanu M, Suciu LC, Manole CG \& Hinescu ME 2011 a Telocytes and putative stem cells in the lungs: electron microscopy, electron tomography and laser scanning microscopy. Cell and Tissue Research 345 391-403. (doi:10.1007/s00441-011-1229-z)

Popescu LM, Manole E, Serboiu CS, Manole CG, Suciu LC, Gherghiceanu M \& Popescu BO 2011b Identification of telocytes in skeletal muscle interstitium: implication for muscle regeneration. Journal of Cellular and Molecular Medicine 15 1379-1392. (doi:10.1111/ j.1582-4934.2011.01330.x)

Qi G, Lin M, Xu M, Manole CG, Wang X \& Zhu T 2012 Telocytes in the human kidney cortex. Journal of Cellular and Molecular Medicine $\mathbf{1 6}$ 3116-3122. (doi:10.1111/j.1582-4934.2012.01582.x)

Ramachandran S \& Palanisamy V 2012 Horizontal transfer of RNAs: exosomes as mediators of intercellular communication. Wiley Interdisciplinary Reviews. RNA 3 286-293. (doi:10.1002/wrna.115)

Rosenbaum ST, Svalø J, Nielsen K, Larsen T, Jørgensen JC \& Bouchelouche P 2012 Immunolocalization and expression of smallconductance calcium-activated potassium channels in human myometrium. Journal of Cellular and Molecular Medicine 16 3001-3008. (doi:10.1111/j.1582-4934.2012.01627.x)

Rusu MC, Pop F, Hostiuc S, Curca GC \& Streinu-Cercel A 2011 Extrahepatic and intrahepatic human portal interstitial Cajal cells. Anatomical Record 294 1382-1392. (doi:10.1002/ar.21441)

Rusu MC, Jianu AM, Mirancea N, Didilescu AC, Manoiu VS \& Paduraru D 2012a Tracheal telocytes. Journal of Cellular and Molecular Medicine 16 401-405. (doi:10.1111/j.1582-4934.2011.01465.x)

Rusu MC, Mirancea N, Mănoiu VS, Vâlcu M, Nicolescu MI \& Păduraru D 2012b Skin telocytes. Annals of Anatomy 194 359-367. (doi:10.1016/ j.aanat.2011.11.007)

Rusu MC, Pop F, Hostiuc S, Curca GC \& Paduraru D 2012c Telocytes form networks in normal cardiac tissues. Histology and Histopathology 27 807-816.

Rusu MC, Nicolescu MI, Jianu AM, Lighezan R, Mănoiu VS \& Păduraru D $2012 d$ Esophageal telocytes and hybrid morphologies. Cell Biology International 36 1079-1088. (doi:10.1042/CBI20120007)

Shynlova O, Tsui P, Dorogin A \& Lye SJ 2008 Monocyte chemoattractant protein-1 (CCL-2) integrates mechanical and endocrine signals that mediate term and preterm labor. Journal of Immunology 181 1470-1479.

Shynlova O, Tsui P, Jaffer S \& Lye SJ 2009 Integration of endocrine and mechanical signals in the regulation of myometrial functions during pregnancy and labour. European Journal of Obstetrics, Gynecology, and Reproductive Biology 144 S2-S10. (doi:10.1016/j.ejogrb.2009. 02.044)

Shynlova O, Kwong R \& Lye SJ 2010 Mechanical stretch regulates hypertrophic phenotype of the myometrium during pregnancy. Reproduction 139 247-253. (doi:10.1530/REP-09-0260) 
Si X, Huang L, Gong Y, Lu J \& Lin L 2012 Role of calcium in activation of hyperpolarization-activated cyclic nucleotide-gated channels caused by cholecystokinin octapeptide in interstitial cells of Cajal. Digestion $\mathbf{8 5}$ 266-275. (doi:10.1159/000337077)

Suciu L, Nicolescu MI \& Popescu LM 2010a Cardiac telocytes: serial dynamic images in cell culture. Journal of Cellular and Molecular Medicine 14 2687-2692. (doi:10.1111/j.1582-4934.2010.01185.x)

Suciu L, Popescu LM, Gherghiceanu M, Regalia T, Nicolescu MI, Hinescu E \& Faussone-Pellegrini MS 2010b Telocytes in human term placenta: morphology and phenotype. Cells, Tissues, Organs 192 325-339. (doi:10.1159/000319467)

Suciu LC, Popescu BO, Kostin S \& Popescu LM 2012 Plateletderived growth factor receptor- $\beta$-positive telocytes in skeletal muscle interstitium. Journal of Cellular and Molecular Medicine 16 701-707. (doi:10.1111/j.1582-4934.2011.01505.x)

Taggart MJ, Arthur P, Zielnik B \& Mitchell BF 2012 Molecular pathways regulating contractility in rat uterus through late gestation and parturition. American Journal of Obstetrics and Gynecology 207 76e15-76e24. (doi:10.1016/j.ajog.2012.04.036)

Takaki M, Suzuki H \& Nakayama S 2010 Recent advances in studies of spontaneous activity in smooth muscle: ubiquitous pacemaker cells. Progress in Biophysics and Molecular Biology 102 129-135. (doi:10.1016/j.pbiomolbio.2010.05.007)

Thomson AJ, Telfer JF, Young A, Campbell S, Stewart CJ, Cameron IT, Greer IA \& Norman JE 1999 Leukocytes infiltrate the myometrium during human parturition: further evidence that labour is an inflammatory process. Human Reproduction 14 229-236. (doi:10.1093/ humrep/14.1.229)

Xiao J, Liang D \& Chen YH 2011 The genetics of atrial fibrillation: from the bench to the bedside. Annual Review of Genomics and Human Genetics 12 73-96. (doi:10.1146/annurev-genom-082410-101515)

Young RC \& Bemis A 2009 Calcium-activated chloride currents prolongs the duration of contractions in pregnant rat myometrial tissue. Reproductive Sciences 16 734-739. (doi:10.1177/1933719 109334965)
Zheng Y, Li H, Manole CG, Sun A, Ge J \& Wang X 2011 Telocytes in trachea and lungs. Journal of Cellular and Molecular Medicine 15 2262-2268. (doi:10.1111/j.1582-4934.2011.01404.x)

Zheng Y, Bai C \& Wang X 2012a Telocyte morphologies and potential roles in diseases. Journal of Cellular Physiology 227 2311-2317. (doi:10.1002/jcp.23022)

Zheng Y, Bai C \& Wang X 2012b Potential significance of telocytes in the pathogenesis of lung diseases. Expert Review of Respiratory Medicine 6 45-49. (doi:10.1586/ers.11.91)

Zheng Y, Zhu T, Lin M, Wu D \& Wang X 2012c Telocytes in the urinary system. Journal of Translational Medicine 10 188. (doi:10.1186/14795876-10-188)

Zhou B \& Pu WT 2011 Epicardial epithelial-to-mesenchymal transition in injured heart. Journal of Cellular and Molecular Medicine 15 2781-2783. (doi:10.1111/j.1582-4934.2011.01450.x)

Zhou J, Zhang Y, Wen X, Cao J, Li D, Lin Q, Wang H, Liu Z, Duan C, Wu K et al. 2010 Telocytes accompanying cardiomyocyte in primary culture: two- and three-dimensional culture environment. Journal of Cellular and Molecular Medicine 142 2641-2645. (doi:10.1111/j.1582-4934. 2010.01186.X)

Zhu Y, Mucci A \& Huizinga JD 2005 Inwardly rectifying chloride channel activity in intestinal pacemaker cells. American Journal of Physiology. Gastrointestinal and Liver Physiology 288 G809-G821. (doi:10.1152/ ajpgi.00301.2004)

Zhu MH, Sung IK, Zheng H, Sung TS, Britton FC, O'Driscoll K, Koh SD \& Sanders KM 2011 Muscarinic activation of $\mathrm{Ca}^{2+}$-activated $\mathrm{Cl}^{-}$current in interstitial cells of Cajal. Journal of Physiology 589 4565-4582. (doi:10.1113/jphysiol.2011.211094)

Received 23 September 2012

First decision 20 October 2012

Revised manuscript received 20 January 2013

Accepted 29 January 2013 